\title{
FINAL REPORT FOR THE PROJECT
}

\section{SITES OF MEMORY: MEMORY OF THE \\ HERITAGE - HERITAGE OF THE MEMORY}

FINANCED BY THE INTERNATIONAL VISEGRAD FUND

WITHIN THE STRATEGIC GRANT PROGRAMME.

\section{Marek FERTIG}

Adam Mickiewicz University, Poznan

The third year has passed (since October 2012) of the project entitled "Sites of memory: memory of the heritage - heritage of the memory", financed by the International Visehrad Fund within the Strategic Grant Programme. The applicant and project coordinator for Adam Mickiewicz University in Poznań is Prof Jaromir JESZKE - head of the AMU Interfaculty Laboratory of Border Questions, who has been studying social and intercultural communication for many years. The project is a continuation of previous research and follows many years of cooperation with Slovak, Czech, and Hungarian partners. The research team of a dozen or so people was divided into national work groups headed by:

- Prof Violetta JULKOWSKA - head of the group from Mickiewicz University in Poznań,

- Dr Maria TONKOVA - head of the group from Comenius University in Bratislava,

- Prof Zdenek BENEŚ - head of the group from Charles University in Prague,

- Prof Ivan HALÁSZ - head of the group from the Saint Adalbert Foundation for the Research of Central and Eastern Europe in Esztergom, Hungary.

The project design and research activities within it focused on the problem, important in the present-day Europe, of the national heritage and sites of collective memory. Sites of memory, understood as suggested by P. Nora, for some are the foundations of identity, pride, and common ties, while being symbols of treason or martyrology for others. An attempt was made within the project both to develop a certain map of sites of memory in the participants' countries and to answer the question if they can affect the mutual relations of their inhabitants. The results of the research, which included mostly the people living in the cultural borderlands of the Visegrad Group countries, can be found in a series of planned publications and partially in this work. 
The progress in carrying out the project and the efficiency of the used research methods were compared during working seminars, each several days long, in Dobczyce near Kraków in October 2013 and a year later in the Polish Cieszyn. The final meeting, summarizing the conducted research was organized in Bratislava in 3-5 December 2015, by the invitation of Comenius Umiversity. The meetings of the Project participants took place within the hospitable walls of the Hungarian Balassi Instutute in Bratislava. All research teams were able to present the results of their work, and their astounding achievements provide motivation for further research. Thanks to many years of contacts contributing to mutual understanding, the scientists shared a great ambiance and held lively discussions.

The topic of the project drew attention of scholars from Slovenia as well, leading to an official invitation for the seminar participants to the Slovenian embassy in the centre of Bratislava. A documentary film, shown during the meeting, depicted the feminist trend in the studies on memory conducted in Slovenia, spurred a long discussion. The pre-Christmas mood in the streets and squares of Bratislava during the traditional Vianoce celebrations was conducive to drawing conculsions and planning future cooperation.

The support of the International Visegrad Fund enabled carrying out significant research work, which are going to become a foundation of many more publications and subsequent projects.

From the perspective of project administration, the financial support from the Fund and partners' contributions can be said to have been a sufficient monetary basis for conducting the planned research and work meetings, develop the website (http://www.memory-heritage.amu.edu.pl), and prepare the translations of the materials and publications summarising the achieved results. The flexible management model and friendly approach of the International Visegrad Fund facilitated attaining the planned goals according to the budget of the project.

Project co-financed by the International Visegrad

Fund within the Visegrad Strategic Grant

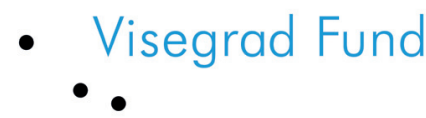


